\title{
Reading between the lines: Hegemonic favouring within language- related communities
}

\author{
Alta Engelbrecht \\ Department of Humanities Education, University of Pretoria, Pretoria, South Africa \\ Email: alta.engelbrecht@ up.ac.za
}

\begin{abstract}
:
Based on the assumption that a struggle to protect the interests of dominant groups exists in all communities, this qualitative study investigates hegemonic favouring in two language-related speech communities. Through the perspectives of focus group participants, the article reports on the discourses in Flemish and Afrikaans communities where certain ideas are presented as a matter of course - as though no alternative exists. In the Flemish focus group discussion, silences surrounding diversity issues were revealed, indicating that a healthy, diverse society where people learn from one another was not yet part of the Flemish psyche. Flemish monolingualism serves as a vehicle for stereotyping the linguistically dissimilar, and is used to maintain hegemonic practices. Demythologisation of Afrikaans history and Standard Afrikaans as undisputed norm freed the language of its previous apartheid enclaves. The pain of coloured speakers of Afrikaans having to dissociate with their home language was foregrounded in the discussion, as well as the fact that there are still many instances where whiteness is the norm against which other ethnic positions are contrasted.
\end{abstract}

\section{Setting the stage}

Seeing is always cultured seeing. What we see, is simply what we (think) we know, as knowledge is the result of the socially structured world we live in (Baldwin, Longhurst, McCracken, Ogborn, and Smith 2004). What happens in that socially constructed world seems normal to its inhabitants and therefore needs not to be questioned by them (Montgomery 2005; Chandler 2014).

This article departs from the assumption that communities protect the interests of the dominant group in order to maintain the social structure they desire (Blommaert 2005; Chandler 2014). Many scholars believe that language forms part of such cultural and socio-political power struggles and that emphasis on language issues is often based on hidden agendas about power and control (Blommaert and Van Avermaert 2008; Van Elst and Prinsloo 2011). Hegemonic favouring, as a result of this, then presents itself through normality thinking or common-sense knowledge (Gramsci 1971) when certain perceptions are presented as normal and matter of course, while in actual fact it is only true in some cases and in some contexts (Balwin et al. 2004; Chandler 2014). Identification of hegemonic practices reveals the ideological way in which 'we' think about 'ourselves' and about 'the other', which is the aim of this article.

Another assumption that this article departs from, is the fact that communities know 'the other' only in comparison to themselves and to the extent to which others are similar or different from them as the norm (Van Dijk 1987, 2008; Botman, Jouwe and Wekker 2001; Bhutani 2008). This is especially true with regard to race. White is not a racial category, but a norm with which everything non-white can be contrasted (Wekker 2002; Deconstruction n.d.). In this regard Vandeyar (2014: 74) refers to 'the unbearable whiteness of being', and Thompson (2001) argues that while blackness and brownness are seen as racial categories, whiteness as an ethnical position does not exist. It is invisible, as it is the norm against which all other ethnic positions, such as blackness and brownness, are measured. In apartheid South Africa, where white supremacy reigned for almost fifty years, this 
was certainly the case, but it could surely be traced further back to colonial times, when Belgium was the colonial power in African countries such as Congo and Rwanda.

At this stage I need to explain the kinship between the Flemish and Afrikaans language communities, the two researched language communities in this article. Although regarded by some as an African language because of its development on African soil, Afrikaans initially originated from Dutch spoken in Belgium and The Netherlands. Dutch spoken in Flanders (the northern part of Belgium) is called Flemish (De Keere and Elchardus 2011). The resemblance between these two kinship languages is of such a nature that speakers of Afrikaans and Flemish understand each other very well. In both communities, language is regarded as a strong cultural index. In Flanders, language and nationalism were combined in the slogan Het taal is gans het volk (The language is totally the people) and after a century's language struggle, Belgium was, in 1995, separated into two regions with Flemish as the official language in the north and French in the south (Lauwers 2006; De Keere and Elchardus 2011). Ironically, at almost the same time, democracy dawned in South Africa and Afrikaans as official language lost its status as one of only two official languages. South Africa now has 11 official languages, although only English is widely considered as the 'official' official language in the new democracy (Van der Elst and Prinsloo 2011). Both languages are in vivid competition with another official world language: French, in the case of Flanders, and English, in the case of South Africa. Both languages were also utilised to exclude the linguistic other (Esterhuyse 1986; Blommaert and Verschuren 1998) as will be expanded on in the literature review.

The above contextualisation compelled me to interrogate data obtained from focus group discussions held in Flanders and South Africa in which visual representations of other-than-white people in mother-tongue textbooks were discussed. Although more differences than parallels exist between these two speech communities, language as cultural marker and how it is foregrounded to organise meaning to frame whiteness as a preferred state of being is the motivation for bringing these two speech communities together in this article. Through Critical Discourse Analysis (CDA), the article reports on the discourses in the two language communities during their discussions of the visual representation techniques of the 'other' in mother-tongue textbooks For the purpose of this article, it is stated clearly that the units of analysis are not the visual material, as it was merely the subject of discussion. The data were the discussions which were observed, video-taped, transcribed and analysed according to Huckin's (2004) strategy to unveil and question the hegemonic practices in the two language communities. The investigation will be guided by the research question: How is hegemonic favouring revealed in Flemish and Afrikaans focus group discussions?

\section{Literature review}

The literature review discusses the socially encoded worlds related to Flanders and South Africa in an attempt to facilitate the discussion of the findings. It discusses the power relations underpinning these language communities. It tries to show the similarities but also the differences between the lenses and filters utilised in service of hegemonic favouring in both language communities. In the last instance, it juxtaposes the way that language, as cultural marker, is employed in both language communities to control social reality.

\section{The socially encoded world in Flanders}

Despite the perception that the Flemish culture, with its multilingual community, reflects linguistic tolerance, it seems as though intolerance towards non-mother tongue speakers with regard to the official language, Dutch, still exists. According to Blommaert and Van Avermaert (2008), purism in language is used to draw race-ethnic boundaries, which inevitably results in the construction of a linguistic other. Dutch spoken by white Flemish people is regarded as the norm from which the Dutch of the so-called anderstaligen (from different language) deviates (Agirdag 2010; Agirdag et al. 2012).

Although a shift from ethnocentrism to cultural relativism has taken place in Flanders since 1975, Homan (2003) maintains that this effort has been nothing more than folkloristic activities. Diversity as a phenomenon and the demographic reality that two out of three children in metropolitan cities do not speak Flemish at home are viewed as a problem that has to be dealt with (Delrue 2003; Lesaffer 
2007; Roose and Pulinx 2014). It seems that this problem is addressed by emphasising Dutch as the only index for survival in Flanders, but also by preventing immigrant students from speaking their home language (Blommaert and Van Avermaert 2008; Agirdag 2010; Agirdag et al. 2012). In this regard, Agirdag (2010: 316) reports on an investigation into bilingualism in Flemish schools:

Our data show that Dutch monolingualism is strongly imposed in three different ways: teachers and school staff strongly encourage the exclusive use of Dutch, bilingual students are formally punished for speaking their mother tongue, and their home languages are excluded from the cultural repertoire of the school. At the same time, 'white' languages such as English, French and German are welcome. Therefore, it would be naive to assume that 'black' languages such as Turkish or Arabic are coincidently disrespected and it is far more plausible that they are linked to the colour, culture, or ethnic origin of immigrant students.

Agirdag (2010) even goes further, suggesting that in Flanders there is 'good and bad' multilingualism. All learners are encouraged to speak other languages, as long as immigrants do not speak their mother tongue.

Furthermore, there is no lowering of the level of academic language competency requirements for immigrants. During a workshop on multiculturality in Dutch classrooms at Artevelde Hogeschool (Gent), Hager (2007) indicated how the achievement of immigrant children could improve through simplification of Dutch as the language of learning. No attempts are currently being made to adapt to the language niveau of second language speakers by, for example, simplifying the Dutch in textbooks used by immigrant children. Even in concentration schools (schools with large numbers of immigrants), Dutch is presented only at home language level.

Agirdag (2009) and Delrue et al. (2006) regard the single medium character of Flemish schools as negation of the multicultural reality in Flanders. According to Delrue (2003), who performed an ethnographical investigation into secondary schools in Flanders, intercultural education as an indicator of quality education is not part of the Flemish psyche. Diversity is still frowned upon as an issue/problem that needs to be addressed. There is no realisation that a rich learning environment where children can learn from one another and where diversity is presented as a normal phenomenon is beneficial to any educational setting (Bhutani 2008; Agirdag 2010; Roose and Pulinx 2014).

Blommaert $(1997 ; 2005)$ even alleges that in Flanders, language is used to marginalise other cultures. Immigrants have to learn Dutch in order to function within the Flemish community, and this results in a 'classical vicious circle' (Blommaert and Verschuren 1998: 132). Without a high level of proficiency in Dutch, immigrants are unable to become part of the community, but it is almost impossible for immigrants to manage the difficult Dutch language. As a result, immigrants seldom become part of the tertiary sector or mainstream education, and they are thus not motivated to acquire Dutch for more than communicative survival in a foreign country (Roose and Pulinx 2014).

The second way in which other cultures are marginalised is by elevating standard Dutch speech to the only norm. According to Blommaert and Verschuren (1998: 129), the Flemish ideological homogeneity refuses to accept language variation as factual phenomenon, except when it refers to the folkloristic level of regional dialects:

A common language simplifies communication. But if a language is thought of as a homogenous instrument, used by all speakers in similar or perfectly comparable ways, so that a common language ensures successful communication, then one suffers from delusions. The anthropological linguistic literature on intercultural communication abounds with examples demonstrating that a homogeneistic lack of attention and appreciation for variation is the preeminent recipe for communication breakdowns.

Standard Dutch becomes the instrument by which immigrants are categorised - not only with regard to geographic dialects or social status as in other languages, but also with regard to ethnicity. Agirdag (2009) and Roose and Pulinx (2014) blame Flemish monolingualism for the alienation of the linguistic other and for the lack of educational achievement of second- and third-generation immigrants. This perspective was recently echoed in a conversation with a sophisticated third-generation immigrant who stated that, although his linguistic competence in Dutch is very high, he is still viewed as an anderstaligen (EI Sgiar 2015). 
Hegemony as a basis of language stereotyping is nowhere as obvious as in the previously mentioned Flemish nomenclature of anderstaligen (Blommaert and Verschuren 1998). Semantically, the word anderstaligen translated, means those who speak a language different from us. Another interesting semantic significance is the similarity the term has with the hegemonic term used during apartheid to refer to non-white South Africans: anderskleurige (which literally means from a different colour than ours). Both anderstaligen and anderskleurige are indicative of the norm that others deviate from (Botman, Jouwe and Wekker 2001; Thompson 2001). In the case of anderstaligen, the norm is Dutch; in the case of anderskleurige, the norm is colour. Furthermore, according to De Figueredo and Elkins (2003) and Agirdag (2010), both words have another semantic value, i.e. that the other is not only different, but also inferior and a threat to the (normal!) citizens. From the discussion, it becomes clear that the Flemish community values their language extremely highly, to such an extent that language serves as the main indicator of cultural inclusion (Roose and Pulinx 2014).

\section{The socially encoded world in South Africa}

Fear of loss has always been a threat to white South Africans. In apartheid South Africa, alongside the fear of black domination, there was also the fear that the Afrikaans language, the so-called marvel of the Afrikaans culture, would be lost in a new dispensation (Vandeyar 2014). Pieterse's (1994) thesis Language politics and alternative Afrikaans presents an informative diachronic and synchronic view of how the mythologising of Afrikaans was used as instrument to instil language hegemony. The myth began by presenting Afrikaans as a marvel; in the first instance the marvel of its origin (Afrikaans originated from European languages such as Dutch, French and Portuguese, but was also influenced by African languages and the Khoi-Khoi language of South Africa's earliest inhabitants). Secondly, the rise from a so-called kitchen language or 'low status language' (Pattynama and Verboom 2000: 20) to medium of instruction in schools and tertiary institutions, and thirdly, the revival of the Afrikaans literature after the Second South African War. All these marvels manifested in the elevation of (white) Afrikaans purism. The standard form of Afrikaans became the undisputed norm and became synonymous with nationalism, on the one hand, and stigmatisation of other varieties, on the other. Coloured people migrated to English as home language and parents started to speak only English to their children (McCormick 2002; Lubbe and Du Plessis 2013). White Afrikaner exclusivity thus led to this tragic rift between white and coloured Afrikaans language communities (Esterhuyse 1986; McCormick 2002; Vandeyar 2014). In South Africa, politically and ideologically, 'coloured' is a controversial term. The term is used to indicate people from a mixed-race origin, also referred to as brown people. Many brown people refer to themselves as black people, out of unity with all non-whites who had been discriminated against during apartheid. During this time (in the 1970s and 1980s) of division between white and coloured speakers of Afrikaans, anti-hegemony campaigns originated as a result of harsh criticism by researchers such as Du Plessis and Du Plessis (1987) and Esterhuyse (1986). The Alternative Afrikaans Movement was established, which strongly opposed white Afrikaner homogeneity by publishing literary texts about the struggle against apartheid in the vernacular of the coloured speakers of Afrikaans, called Cape Afrikaans.

Over the last twenty years, demythologising of Afrikaans as the white man's language has occurred in the press in South Africa (McCormick 2002; Lubbe and Du Plessis 2013). Intensive research about the origin of Afrikaans has led the author Achmat Davids to state: 'Afrikaans, the language of the white tribe of SA, is a black tongue' (Harvey 2000: 1). The oldest recorded Afrikaans texts are indeed in Arabic - Abu Bakr's Afrikaans translations of sections of the Koran (Van Rensburg 1997; Harvey 2000). Afrikaans was popularised by authors like Davids and Willemse, and it soon became general knowledge that of the 6.9 million home language speakers of Afrikaans, only 2.7 million were actually white (McCormick 2002; Lubbe and Du Plessis 2013). Afrikaans was again used as a political instrument, but in this case as a label for the ideology of liberation (Pieterse 1994; Van der Elst and Prinsloo 2011).

A new dispensation brought new role players and new insights when white South Africans were forced to abandon not only their white supremacy and exclusivity, but were also forced to migrate to new strategies, attitudes and allies. The varieties of Afrikaans, for the first time, received positive recognition and became 'objects of interest, rather than scorn' (Lubbe and Du Plessis 2013: 125). 
The one section of the Afrikaans language community (the coloured and Indian speakers) who were racially oppressed in the past and the other section (the previously white oppressors) became allies, condemning the discrimination against Afrikaans as a result of the new ANC government's hegemonic practices in favour of English (Deumert 2010). English hegemony in South Africa was attacked from different resorts. The late professor Neville Alexander, a distinguished coloured academic from the University of Cape Town, warned that the language imperialism of English was at the expense of most children and students in South Africa (Van der Elst and Prinsloo 2011). In Brussels, the Unrepresented Nations and People's Organisation (UNPO), an influential international organisation, consisting of 71 member countries campaigning for minority rights, adopted a resolution at their congress condemning discrimination against Afrikaans (Lubbe and Du Plessis 2013). Role players from different societies were suddenly united in their linguistic strife to ironically defend a language that was not long ago only known by the world because of one word, 'apartheid'.

To strengthen and legitimise the language, Afrikaans had to play its part in the euphoria of the so-called new rainbow nation that was created after democratisation in 1994. This was nowhere as visible as in the visual representations in Afrikaans school textbooks written for the new democratic dispensation. Ensuring counter-stereotypical representations that reflect a new South Africa in which colour and race play no part (Engelbrecht 2008) was the order of the day. Engelbrecht (2009) investigated stereotypical representations in Afrikaans textbooks and found no stereotypical images in the sample. What she did find was an unauthentic world in which all South Africans speak Afrikaans and in which racial tension does not exist, contrary to the real world in which racial sensitivity in South Africa is still a reality. This finding coincides with an observation by Kusendila (2003), who compared a Flemish and Afrikaans textbook series in terms of identity issues, and found that a social world is constructed in Afrikaans textbooks where voices of characters of other languages are not truly heard, as all people (black or white) are depicted as speaking Afrikaans as though it were their home language. The reality in modern-day South Africa is that most black people refuse to speak Afrikaans because of the negative association with the language during the reign of apartheid (Deumert 2010; Lubbe and Du Plessis 2013).

The impact of apartheid and the moral dilemma that was consequently created seem to be the most important factors that forced Afrikaans to become more inclusive (Lubbe and Du Plessis 2013). During apartheid, language stereotyping and language exclusion were used to maintain white Afrikaner superiority (Deumert 2010). Democracy paved the way for a new language unity and Afrikaans identity, by embracing all of its (previously scorned) speakers and by shying away from language purism and Standard Afrikaans as uncontested norm. By attempting to rid itself of these internal conflicts, language openness in which religious and cultural differences are not only tolerated, but appreciated, became the new norm.

From the above discussions, it becomes clear that both communities share the defining role of language employed in service of sociopolitical power struggles. The differences regarding diversity and cultural perspectives, however, seem to be even more significant in the comparison between the two speech communities. Mutual origin and the fact that Afrikaans is a daughter language of Dutch seem not to be as significant as might have been believed. The meaning-making lenses and filters utilised to construct the self and the other are determined contextually and are of much more significance than the kinship between the languages.

\section{Methodology}

This qualitative study tried to obtain an insider perspective from knowledgeable individuals through focus group discussions on diversity issues in their respective communities. Participants were purposefully sampled. Participants were chosen because of their interest in, knowledge of and involvement in diversity and multicultural education as phenomena. I was interested in the perspectives of focus group members to obtain data that were not readily available anywhere else (Babbie and Mouton 2001). They were either experts in the field of diversity or had experience in working in multicultural workplaces. Furthermore they were strong personalities, opinionated and politically informed. The composition of the groups was the main reason for opting for only one focus group in each country. In this regard, Blommaert (2013: 2) explains the validity and agency of such a 
small, purposeful gathering of people united only in the purpose of the discussion:

We started looking inside such groups, searching in the 'infra-group' diversity if you wish. And when you see within social, cultural and linguistic groups, of course, you get an even more outspoken diversification of diversity, in the sense that within groups you see enormous amounts of multiplicity, hybridity and complexity. You also see the creation of ephemeral groups that have the solidity actually or the degree of solidity and certainly the agentivity of the big 'groups' that we know - like nation states or ethnic groups, religions and so on. A group of spectators in a bar watching a football game is as robust a group as a 'nation', even if that group only lasts for a couple of hours.

Three factors are important in this regard. Firstly, the focus group differed from an ordinary focus group in the sense that the participants became stakeholders in my study as informative intellectuals in the discourse of diversity. Secondly, after the focus group discussions, I was also in email contact with the participants as a form of member-checking and to probe for deeper discussions on certain topics that emerged from the data (e.g. the email correspondence mentioned in the findings below). In the third place, a pilot study preceded the focus group discussions whose original aim was to ensure that the data collection would produce credible results, but in the end provided such strong data that it was added to the data set as a whole.

Data on how the (non-Western and non-white) 'other' was projected in visual representations were obtained through one focus group discussion in each country. The participants were asked to discuss how other-than-white people were represented in random examples of visual material used in school textbook series from their country. They discussed examples of different visual genres such as photographs, drawings and cartoons.

The focus group discussions lasted approximately two hours and were facilitated by a lecturer from a tertiary institution in Gent (Belgium) and in Pretoria (South Africa), who were briefed by me in terms of the procedure to be followed and the material to be discussed. An assistant in both countries was responsible for taping the focus group discussions. I could therefore focus on observing the discussion between the participants, picking up verbal and non-verbal cues on a personal and intellectual level, which assisted me in the analysis phase. I refrained from participating in any way that would compromise the data. The discussions were transcribed and analysed according to Huckin's CDA strategy (Barton and Stygall 2002: 1-27; Huckin 2004: 1-15) to unveil the hegemonic practices in the two language communities. The visual material that was discussed was instrumental in obtaining the perspectives of the participants who were either insiders (a white Flemish or Afrikaans identity) or outsiders (had an other-than-white identity). Huckin's strategy consists of two phases. The first phase is an uncritical reading of the text as if one were a 'typical reader'. It entails a mere description of what physically is in the text. In the second phase, deliberate distancing is required in order to ask critical questions that could reveal normality thinking. These questions referred to different levels of meaning-making, such as connotations and associations, voice(s), the agent/patient relationship, assumptions and obviousness to gauge the reasons for claims made, and motivations for findings.

\section{The sample}

As mentioned, the visual material was in no way the object or the phenomenon of this investigation. From a Dutch and Afrikaans textbook series which did very well in the school textbook markets, I chose five to seven representations from different visual genres, e.g. cartoons, photographs or drawings, to be discussed. Figures S1-S4 are examples from the sample. The textbooks were thus generally used and should reflect the general norm of society, but these texts were only used to facilitate the discussion in a creative and interesting manner. Furthermore, visual texts speak a universal language and therefore visual representations would be more open ended than textual representations and would evoke culture-specific responses (Prosser 2001; Seale, Gobo, Gubrium, and Silverman 2004).

The focus group offered a unique platform to gauge normality thinking in both language communities from opposing perspectives. All participants were involved in the educational sphere to some extent. I deliberately chose participants from different races and cultures to obtain as many perspectives as possible on the discursive practices within the two language communities. 
The participants were mainly lecturers from higher institutions in Gent (Flanders) and Pretoria (South Africa). For the Flemish sample, teachers and a school principal were also sampled, as I struggled to find participants from the tertiary sector who were from any other origin than white. In Flanders, the sample consisted of four white men (three lecturers and a school principal), one female Turkish lecturer, one male Moroccan lecturer, one male teacher originally from Suriname, and one female teacher born in Korea, but raised by white Flemish parents. In South Africa, the focus group consisted of three white lecturers (one male and two female), two coloured lecturers (one male and one female) and one black lecturer (female). Although not generalisable because of the small sample, the participants did resemble the socially structured world and the questioning thereof to reveal hegemonic favouring.

\section{Theoretical foundation}

The theoretical lens informing the analysis, in an eclectic way, drew from different fields such as intercultural studies, cultural studies, critical theory and the principles of Critical Discourse Analysis. Cultural studies, with its emphasis on whiteness as the preferred state of being, firstly and foremost directs the study. Then the lens of critical theory was applied to the data, unravelling the systematic appearance of entitlement behind obviousness, which are followed by Sierens's markers to evaluate intercultural representation. These markers, Huckin's strategy and the questions asked in a CDA analysis guide the analysis of the discussions as it systematically reveals how participants (unknowingly and unconsciously) react from an invisible position of power.

Discursive theories on whiteness (as articulated in post-structural, colonial and cultural studies) depart from the assumption that whiteness is a sociopolitically constructed position of power. Its power lies in the fact that whiteness is unnamed and unquestioned (Henry and Tator 2006), as whiteness is never required to explain itself. It is the dominant culture that sets the norm against which every other culture is measured, therefore it has the structural advantage of being 'normative natural' (Henry and Tator 2006: 46). Thompson (2001: 20) also describes whiteness as a 'preferred status' and hooks (1992) describes it as an unconscious and invisible state of being that defines the world only in terms of deviation from its preferred status. In this regard, Painter (2015: 8) refers to whiteness as 'the toggle between nothingness and awesomeness', and Thompson (2001) points out that, although a preferred status, it is also a threatened status, as it alerts against the privileges to which white culture is entitled.

The analysis of discourse within a society is a critical analysis of the voice within society (Van Dijk 1987; 1993; 2008; Wodak and Meyer 2015). Blommaert (2005) describes this voice as the way in which the dominant group within a society succeeds in making themselves clear, while at the same time also (unconsciously) defining inequality. CDA tries to support the victims of hegemonic suppression and motivates them to confront this suppression. At the root of the critical discourse of identity and difference lies the construction of binary oppositions. There are four underlying questions (Seale et al. 2004) that define these binary positions in CDA and these will guide the analysis and the report of this study:

1. How are people called or talked about?

2. Which characteristics, qualities and aspects are attributed to people?

3. Which arguments or frameworks are used to justify inclusion and exclusion practices of specific people or social groups?

4. Which agendas, perspectives or assumptions are underlying the labelling, the arguments or the attributions made to certain groups or individuals?

The following indicators for a healthy diverse environment, coined by Sierens (2007) through the intercultural organisation of the University of Gent (Flanders), deliberately counter the rhetoric of whiteness and hegemonic favouring.

1. Normality: diversity is a normal phenomenon in society.

2. Multiple identities: people are portrayed as ordinary and unique.

3. Non-judgemental: generalisations, judgements and stereotypes are countered.

4. Discrimination and perceptions: the mechanisms at work in service of racism and discrimination are revealed and discussed. 
5. Multiple perspectives: Eurocentrism regarding minorities as invisible are countered.

6. Interaction and variation: people from different identities interact and learn from each other.

7. Authentic learning contexts: tasks, assignments, exercises and sources consider environments that reflect social reality.

8. Accessibility: different identities can comprehend and identify with material presented.

These indicators search beyond overt stereotyping and prejudice to the deeper level of commonsense assumptions, as does Huckin's CDA strategy. These theoretical impetuses will be used as a lens to inform the analysis and facilitate the discussion of the findings.

\section{Findings}

\section{Report on the focus group discussions in Flanders}

Two observations are relevant for the discussion. Firstly, the level of the discussion was high, mainly because of the participants' culture-specific perspectives and their knowledgeable interpretations. Secondly, there was a gradual increase in the positioning of Participant 1 at the one end of the discussion, questioning the hegemonic practices critically from an immigrant perspective. He was supported by the other non-white participants, but he strongly took the lead and the others followed. On the other spectrum were the white in-group, who initially dominated the discussion but eventually was overpowered by Participant 1 so that they were obliged to fulfil the role of defending, explaining or confirming the discursive practices that were outlined by Participant 1 . For the purpose of clarity, I will refer to participants in terms of their race, e.g. P1(b) will refer to Participant 1 (black) and P1(w) will refer to Participant 1 (white).

The following themes emerged from the analysis of the discussion:

\section{Focus is on the origin or the religion of immigrants, rather than on realistic and authentic} representations

$\mathrm{P} 1$ (b) stated that when portraying immigrants in the textbook, the emphasis is on their origin (Blommaert and Verschuren 1998; Roose and Pulinx 2014). The neighbourhood, streets and environment where they live and work is the reality of, for instance, a Moroccan family in Flanders, but in representations in the textbook they are mostly linked to their country of origin or religion. They are always portrayed in traditional clothes or against a setting from their country of origin. He further commented that although it may seem that there was room created for the representation of immigrant children in the textbooks, the opposite is true, because the unauthentic representations (always linked to either the country of origin or religion) only underline their strangeness and how they differ from traditional Flemish children:

Why are only pictures of the country of origin shown to describe Moroccan children in

Flanders? Their everyday experiences are not of the Great Mosque or of Casablanca; they would rather recognise and identify themselves with the vicinity, the region, the neighbourhood or the street in Flanders where they currently live.

In this regard, both Delrue (2003) and Agirdag et al. (2012) plead for Flemish schools to recognise the milieu of the immigrants in classroom encounters. This discussion unveiled the ideological way in which the white Flemish community think about themselves and about the other. The white in-group in the focus group discussion was surprised at this allegation. They did not defend the allegation and from their non-verbal reaction it was clear that they have not previously considered the fact that immigrants are portrayed according to their origin, religion and not according to the demographic reality that two out of three children in Antwerp have another home language (Lesaffer 2007). Their reaction demonstrated the assumption of Whiteness theories (Frankenberg 1988; Painter 2015) that white people live in an unconscious and invisible state of being (hooks 1992) that is a natural and preferred status (Thompson 2001; Henry and Tator 2006).

After having paged through the textbook under discussion, P1(b) continued:

This is clearly the norms of white families. It creates problems when so many learners are not part of the norm. Within a community, one often departs from a certain generally accepted norm (which is not necessarily based on reality). If reality is the norm, why would we deny that most learners in large cities are of foreign origin? 
The above quotation from P1(b) also corresponds with the whiteness theories (Frankenberg 1988; Thompson 2001; Henry and Tator 2006; Vandeyar 2014) that indicate that white is the norm against which all ethnical positions are compared, and that the dominant white culture neither needs to explain itself nor realises their sociopolitically constructed position of power. It also comments on Sierens' first indicator, that diversity should be regarded as a normal phenomenon in a multicultural society.

Certain cultural or religious practices represented in the textbooks attested to a lack of knowledge, respect, and a positive attitude towards cultural practices of others (Sierens 2007: indicators 5, 6 and 7). Comments made by different members of the focus group, for example, criticised the way in which the headdress (burka) was worn in one of the photographs. According to them, a particular picture created the impression that a girl merely wrapped the headdress around her head after exercising, rather than wearing it as a culturally inspired dress:

P2(w): Young woman wearing a piece of material while jogging (that's what I would say, not

seeing the caption).

P5(b): Young foreign women wearing a headdress...Is the headdress worn correctly?

In this example the authenticity of a presented learning context (Sierens 2007: indicator 7) is in question. All participants agreed that the fact that cultural practices seem not to be presented in an authentic manner suggests a lack of identification possibilities for immigrant children, as a Muslim child would recognise that this is not the correct way a headdress would and should be worn (Sierens 2007: indicator 6).

\section{The immigrant as a problem}

According to P1(b), more than half the visual texts discussed were taken from a chapter in the textbook entitled The book culture, which was dedicated to diversity. The chapter is divided into sub-themes such as Cultural freedom; How far should one go?; I am but a Jew and After apartheid. The remainder of the book contains very little visual material in which the normal everyday (diverse) Flemish society is depicted (Sierens 2007: indicators 1, 2 and 7). Foreigners are not portrayed as ordinary, unique people, which again indicates that diversity is not viewed as a normal phenomenon in society (Agirdag 2010). By discussing diversity as a phenomenon, rather than presenting the multicultural nature of the current Flemish society, immigrants are framed as a problem to be handled by the 'normative natural' (Henry and Tator 2006: 46). P1(b) also mentioned that, in itself, the fact that the question How far should one go? is asked in this chapter is ironic, as intercultural practices are actually based on the breaking of boundaries and a learning environment in which diversity is perceived as beneficial to educational settings (Delrue 2003; Roose and Pulinx 2014).

P1(b) then referred to a semantic unity in the chapter on diversity, which deals with female circumcision in Somalia as an example of how concealed labelling operates in order to establish 'a high versus a low culture' (Pattynama and Verboom 2000: 26). According to P1(b), female circumcision is very rare and unknown to most Muslims in Flanders. The photo and accompanying report in the textbook create a link between all Muslims and female circumcision, which gives rise to stigmatisation, generalisation and stereotyping (Sierens 2007: indicators 3 and 4).

The focus group participants all agreed that humour was used to foreground certain perceptions pertaining to the subservient role of women in the Muslim community. With reference to the cartoon (Figure S1), P1(b) reacted as follows:

A man, once again someone from Islam, North African or Middle Eastern descent (due to the moustache and combed eyebrows), and a Western girl (Pippi Longstocking) wearing a burka, while retaining some characteristics of her personality. A reference of how Muslims force their way of life onto non-Muslims. The girl, wearing a burka, walks behind the man - a stereotypical image of Muslims. Even though the man is dressed modernly, it seems as though his traditional character persists.

P8(b) contended:

Pippi now wears a veil and walks behind her man. She has retained her individuality by preserving her pigtails and stockings. The man does not seem to be very friendly.

In this extract the problem of the threat of the other (De Figueiredo and Elkins 2003) is openly 
addressed in a humorous representation. We (Pippi Longstocking) are tolerant and white; they (Muslims) are problematic, threatening and deceptive (Sim and Van Loon 2002). The caricature alarmingly warns against the threatened status of whiteness (Thompson 2001).

\section{We and they (us and them)}

Referring to a photograph of a painting (Figure S2) in which a young man is depicted (Casteleyn et al. 2005: 92), everyone agreed that the photograph was in no way stereotypical; in fact it seemed to be presented very positively. P1(b), however, referred to the text within the painting, 'Some wild, some tame', which brought a new dimension to the fore:

In this instance wild and tame could both be humiliating and racist, as these terms are usually used with reference to animals: The term wild...Wild as opposed to tame has to do with animals. Wild is okay; - that is not so bad, but tame really refers to animals. Only animals are tame.

P1(b) hereby actually accused the authors of the textbook of comparing black people to animals by referring to them as wild or tame. The mechanisms at work in service of racism and discrimination (Sierens 2007: indicator 4) are revealed through this semantic episode. The discussion reveals clearly that Whiteness is the undisputed norm, creating a so-called higher and lower culture, as well as a threatened white status of being, warning against the danger of non-white intruders (Thompson 2001; Henry and Tator 2006; Painter 2015).

Furthermore, the painting illustrates a passage from South-African Nobel prize winner, JM Coetzee's book Disgrace, in which Lucy, one of the characters is raped by a black man. The focus group discussion therefore foregrounded that if one realises this contextualisation, the painting creates the impression that some black people are tame (fit perfectly into Western society), but that others cannot be tamed. According to Sierens (2007: indicators 3, 4 and 5), Eurocentric and discriminating perceptions are foregrounded here, which do not serve the purpose of a healthy, diverse community.

\section{Discussion of findings}

The common-sense nature of ideology (Deconstruction n.d.) and the fact that there are always 'wider ideologies at work in a society' (Rose 2001: 43) are revealed through this focus group discussion. In the material under discussion, individuals and groups from other than white and Flemish origin were not represented as diverse, normal, unique people in everyday circumstances. The focus in the visual representations was not on the similarities, but on the differences between people (Roose and Pulinx 2014). The common-sense perspectives of most of the white participants prevented them from sufficiently recognising the reality of diversity in Flanders. Only when they were forced by P1(b) to look in a critical manner at the complex mechanisms underpinning representational practices, the misrepresentations became visible to them. In the end, it was acknowledged by the participants that limited identification possibilities and representational space were awarded to the linguistic other and that in most cases the representations were in fact stereotypical.

\section{Report on the focus group discussion in South Africa}

Two observations are relevant for the forthcoming discussion. As in Flanders, the intellectual level of the discussion was high because of the participants' culture-specific perspectives and their knowledgeable interpretations. Again there was one participant who dominated the discourse, questioning hegemonic practices critically from an outsider and other-than-white perspective. He was supported by the other non-white participants. On the other spectrum was the white in-group, who seemed to be divided in terms of their approach to the discussion. They did not support one another to the same extent that the non-white in-group did and their participation styles were different from each other. One participant had an objective and matter-of-fact style and refrained from participating in contentious issues, another was very self-assured and did not shy away from conflicting opinions, while yet another participant almost positioned herself in the middle of the other two, engaging in a bridging role where she constantly tried to play down the tension in the discussion. The following themes emerged from the focus group discussion in South Africa: 


\section{Race sensitivity}

The focus group discussion in South Africa differed notably from that in Flanders in that an underlying racial sensitivity was evident - probably indicative of the underlying tension that still exists as a result of the apartheid era. In the first instance, there was tension about terminology. P2(b) used the term 'black' to describe a portrayed character, and P7(w) remarked that the character was coloured and not black. P2(b) then answered that she had used the term generically. The tension lies in the fact that some coloureds, in solidarity with blacks, distanced themselves from the term coloured and referred to all non-whites as black (Esterhuyse 1986; Lubbe and Du Plessis 2013).

Thompson (2001) and Vandeyar (2014) argue that white is not a racial category, but a norm with which everything non-white can be contrasted. By using the term black generically for non-white, P2(b) was actually referring to the fact that white is the norm from which other references deviate. The fact that $\mathrm{P} 7(\mathrm{w})$ showed no understanding of the way in which the non-white community regards naming of colour confirms the lack of understanding and communication that sometimes still exists between blacks and whites in South Africa. An even better example of how white is presented as the matter-of-course norm was when P5(w) mentioned that a coloured character in the sample looked like a 'normal Afrikaans child', (implying normal to be a white child). Here normal is used as synonym for white and it clearly shows how whiteness acts as the common-sense norm in society (Thompson 2001; Wekker 2002; Deconstruction n.d.).

In the second instance, one of the members of the focus group, in an email sent immediately after the discussion, confessed that she had not presented her personal view in all instances, but that she had weighed her words throughout in order not to be insensitive towards 'them':

I was shocked at my own reaction. I was definitely inhibited and did not say what I normally

would. I was afraid that my opinion might be regarded as being insensitive towards them. I

concentrated on formulating and naming in such a way that they would not feel that I was aware of colour.

This participant's confession does reveal a glimpse of what Pieterse (1994) calls anti-hegemony. She was in fact so conscious of the power struggle and racial tension that underpinned the discussion that she (unknowingly) tried to shy away from anything that could link her to racial hegemonic perspectives during the discussions. It certainly does emphasise the lack of communication and trust between white and non-white South Africans, even though on the surface (in the sampled textbook) it is portrayed as if colour is simply not an issue in South Africa anymore (Engelbrecht 2009).

\section{Authenticity of the presentations}

Although there was consensus between the participants about the deliberate countering of the polarisation between 'us' and 'them' in the textbook, and the positive portrayal of the previously marginalised in all the illustrative material, a discussion arose which penetrated the essence of normality thinking in South Africa. Lethabo, the 'successful, passionate and intelligent' (P5(w)) worker at an insurance company was discussed. P1(b) regarded Lethabo's language (she spoke Afrikaans in the advertisement) as artificial:

I was looking at the use of language, and the direct translation of sentences and whether

Lethabo would speak like that. I would find it extremely difficult if she speaks like that, unless

it was translated from English to Afrikaans, and it's given a particular meaning. But I would not see Lethabo speaking like that.

One of the previously mentioned findings of Kusendila (2003) was that in Afrikaans textbooks a world is constructed where all people speak Afrikaans, which is not the case as most black people prefer to speak English. P1(b) was evaluating the representation in terms of the everyday South African reality, and found the voice (Huckin 2004) used by the actor in this advertisement as not credible (Sierens 2007: indicator 7).

Secondly, the group felt that, with regard to sport and entertainment, the representations were from the cultural spectrum, but P5(w) mentioned that the visual representations in the first and last editions of the discussed textbook were different. A black athlete (the tennis player, Serena Williams) was deliberately included in the last edition (Le Cordeur et al. 2007: 91). P1(b) questioned this by asking why a South African athlete was not used. Adding the tennis star to the last edition was a 
deliberate attempt to add black sport heroes, which could not be found in South Africa. He then suggested that this was an unauthentic presentation: 'It could have a negative effect. You can't get black people who are successful in sport. You have to go American'.

Through his reaction, P1(b) suggested that, although there was an obvious and purposeful countering of stereotypical representations (Engelbrecht 2009) in the textbook under discussion, authenticity with regard to the trustworthiness of portrayed characters and role models could be questioned (Engelbrecht 2008), again indicating the discrepancy between the utopian world constructed in the textbook versus the real world where black heroes cannot be found.

\section{We and they, us and them}

The group commented on the examples of varieties of Afrikaans found in the textbook. There were various visual examples of dialogues in Cape Afrikaans, Griqua-Afrikaans and Northern Cape Afrikaans. P5(w) regarded this as an attempt at recognition for all speakers of Afrikaans (Lubbe and Du Plessis 2013; Vandeyar 2014). However, P1(b) had reservations about the use of language variety:

If you see white people speaking just one kind of Afrikaans, while you portray other people speaking different types of Afrikaans...I would like to see that in the book; do they do that? Do they conveniently see white people as one, above all other people? If white people don't speak the same type of Afrikaans... if the author is doing that...

The reservations voiced by $\mathrm{P} 1$ (b) were that the varieties should not always be represented as non-white, as this could be regarded as stigmatisation, while white people all speak in the same way which again refers to white homogeneity (Lubbe and Du Plessis 2013; Vandeyar 2014). The reservations by P1(b) were invalidated when the group viewed an example of two white people speaking Northern Cape Afrikaans (Figure S3). From this discussion, it became clear that the varieties of Afrikaans indeed received positive recognition in the Afrikaans community (Van der Elst and Prinsloo 2011; Lubbe and Du Plessis 2013; Vandeyar 2014). 'Geelkeelkanarie', a poem written in the normative Standard Afrikaans by the poet Boerneef, was illustrated as performed by a modern, young, black singer (Figure S4), thus creating a positive and regenerating association. P7(w) reacted as follows:

What is important to me, what is positive, is that I thought that my Afrikaans was the only real Afrikaans which is ours; this is contradicted here...I think what I personally find meaningful is that in an Afrikaans school, as a white person, you grew up with that picture and that was all there was...Now you are confronted with the truth (that not only white people speak Afrikaans) and it is fitting.

Through this comment (from a white perspective) the demythologisation of Standard Afrikaans and the redemption of its speakers from exclusivity and stigmatisation became evident (Sierens 2007: indicators $3,4,5$ and 6 ). White homogeneity was countered not only in the visual representation, but by $\mathrm{P} 7(\mathrm{w})$ appreciating the way in which attitudes have changed in the Afrikaans community. It seems that Afrikaans has gradually become an authentic home for all its speakers.

\section{Politicising Afrikaans}

The discussion about language variety naturally developed into a discussion about the politicising of Afrikaans. P7(w) once again referred to the fact that language textbooks are politicised. This statement gave rise to intense debate. $\mathrm{P} 5(\mathrm{w})$ was of the opinion that the teacher should use language as a subject to educate learners who might experience gaps in their recognition of history. P1(b) and P2(b) maintained that it was about more than general history, namely about the history of Afrikaans. The language stereotyping of the past had to be neutralised.

P1(b): I think the South African context has relevance, because Afrikaans is so highly politicised, and they explain it in relation to June 16, Sharpeville...political incidents...So, for me, it's exactly that: the history of relevance that they do engage with... It's not a separate history issue; it's about the history of Afrikaans. If you want to be inclusive, you have to acknowledge that!

P2(b): That's why I think a lot of white people struggle with the fact that there's more black people who speak Afrikaans as a home language than white people. You would never say 
Afrikaans is my 'huistaal' (home language), because we dissociate. I find myself speaking Afrikaans again for the first time at the university now. It kind of goes back to... because we actively dissociate with Afrikaans and then also I think that certain pockets of communities might see black people who speak Afrikaans as the working class. It will educate you if you speak English. All these issues are going through my mind as I'm saying this.

The rift between the white and coloured Afrikaans language communities (McCormick 2002; Vandeyar 2014) became evident through this discussion. P1(b) and P2(b) revealed the extent to which the apartheid past still impacted on them and how painful it had been to actively dissociate with one's own language (McCormick 2002; Lubbe and Du Plessis 2013). There was not much empathy from P7(w), who insisted on the fact that political content in a language textbook is not appropriate. The need for reflecting on the history of Afrikaans 'if you want to be inclusive' (P1(b)) sums up the moral dilemma that forced white Afrikaans speakers to become inclusive of language and cultural differences (Lubbe and Du Plessis 2013), but it also reveals that old habits die hard and that white Afrikaners do not always understand the pain caused by the rejection experienced by coloured speakers of Afrikaans in the past.

\section{Confronting the previous dispensation}

The extent to which the apartheid past and nation building were addressed in the visual texts and the mechanisms at work to counter racism and discrimination in the visual representations were brought to the fore (Sierens 2007: indicator 4). The positive way in which the visual material addressed the apartheid past was not echoed in the interaction between the focus group members. A white focus group member (P7(w)) again commented on the fact 'that so much political content appeared in a language textbook'. P1(b) instantly reacted by asking why he regarded illustrations (which were about human rights) as political. According to P1(b), information about social development and humanitarian principles are necessary pillars of a democratic state and has nothing to do with 'politics'. This remark suggested that whites are (still) threatened by human rights issues as a result of the fact that human rights were ignored for so long in the past. The remark was supported by P2(b), who added that such a view (of human rights being seen as political) would be found only in South Africa - thereby suggesting that apartheid perceptions in South Africa have not yet changed.

\section{Discussion of findings}

Since 1994, the emphasis on purism, elitism and white supremacy in Afrikaans textbooks has been replaced by a more accessible, inclusive and varied projection of language. However, the ideal world constructed in textbooks was not echoed by the general discourse in the Afrikaans speech community, as reflected in the focus group discussion. Race-sensitivity was still very much a reality and revealed the lack of communication and trust between white and non-white South Africans. There were instances of shying away from confronting the apartheid past by not recognising the pain of those who so profoundly suffered during the apartheid era. On the contrary, accepting and appreciating the language variety of all Afrikaans speakers revealed that colour was no longer the only index of cultural inclusion. The demythologisation of Standard Afrikaans as the marvel of the Afrikaans culture acted as an anti-hegemonic mechanism, which freed the language of its previous enclaves. Hegemonic favouring was revealed in the Afrikaans focus group discussion to the extent that it became apparent that apartheid perspectives have not sufficiently changed.

\section{Conclusion}

Although the hegemonic favouring in the two communities is built on very different past and present circumstances, the 'common-sense knowledge' (Gramsci 1971) of the participants in both focus group discussions was questioned, and instances of ideological hegemony were revealed. Different kinds of hegemonic favouring were found, in spite of sharing the 'same' language. The discourses investigated through CDA culminated in two major observations. First, when whiteness is recognised and acknowledged as the norm according to which everything else can be contrasted, diversity 
as a phenomenon can be constructed in a new way. Second, the role of language as a control mechanism of social reality should be understood and deliberately reflected on. In both Flemish and Afrikaans communities, the role of language homogeneity was foregrounded as an obstacle in creating a healthy diverse environment. In the Flemish community, monolingualism is used to portray the linguistic dissimilar as 'the other', and in the Afrikaans community, white homogeneity still serves as the norm, although the doors were opened for allies from the other-than-white Afrikaans speech communities. The indicators of a healthy diverse society (Sierens 2007) can only be viable when the ideological way in which whiteness and language influence social filters is acknowledged. The application of the discursive theories on whiteness to the data and the probing thereof on the deeper levels of meaning clearly mirrored the struggle to protect the interest of the dominant, white Flemish in-group as well as the previously advantaged white minority in South Africa. Furthermore, language does not only serve as a cultural marker, but also elucidates aspects of society, such as stereotyping the linguistic dissimilar to maintain hegemonic practices or realising that colour was no longer the only index of cultural inclusion. Although not generalisable because of the small sample, the participants did resemble the socially structured world and the questioning thereof to reveal hegemonic favouring.

\section{References}

Agirdag O. 2009. All languages welcomed here. Educational Leadership 66: 20-25.

Agirdag O. 2010. Exploring bilingualism in a monolingual school system: Insights from Turkish and native students from Belgian schools. British Journal of Sociology of Education 31(3): 307-321. http://dx.doi.org/10.1080/01425691003700540.

Agirdag O, Nouwen W, Mahieu P, Van Avemaert P, Vandenbroucke A, Van Houtte M. 2012. Segregatie in het basisonderwijs: geen zwart-wit verhaal. Antwerpen: Garant.

Babbie E, Mouton JA. 2001. Social research. Cape Town: Oxford.

Baldwin E, Longhurst B, McCracken S, Ogborn M, Smith G. 2004. Introducing cultural studies. London: Pearson Education.

Barton E, Stygall G (eds). 2002. Discourse studies in composition. Cresskill: Hampton Press.

Bhutani S. 2008. Schoolboeken bevestigen clichés. Available at: http://minderhedenforum.be/ onderwijs/300804Schoolboeken.htm. (Accessed 11 December).

Blommaert J. 1997. The slow shift in orthodoxy: (Re) formulations of 'integration' in Belgium. Pragmatics (Special issue on Conflict and violence in pragmatic research) 7(4): 1-27.

Blommaert J. 2005. Discourse: A critical introduction. Cambridge: Cambridge University Press. http:// dx.doi.org/10.1017/CBO9780511610295.

Blommaert J. 2013. Ethnography, superdiversity and linguistic landscapes. Chronicles of complexity. Sociolinguistica 28(1): 213-215.

Blommaert J, Van Avermaet P. 2008. Language, education and the society. The gap between policy and reality. Berchem: Epo.

Blommaert J, Verschuren J. 1998. Debating diversity. Analysing the discourse of tolerance. London: Routledge.

Botman M, Jouwe N, Wekker G. 2001. Caleidoschopiesche visies: De zwarte, migranten en vluchtelingen-vrouwenbeweging in Nederland. Amsterdam: Koninklijke Instituut voor de Tropen.

Casteleyn J, Cocquyt L, Crommelinnck D, De Maesschalk Y, De Paepe J, Debbaut R. ... Vandercammen H. 2005. Markant Nederlands 6 Bronnenboek. Kappellen: Pelckmans Uitgeverij.

Chandler D. 2014. Marxist media theory: Gramsci and hegemony. Available at: http://www.cym.ie/ documents/chandler.pdf (Accessed 30 July 2015).

Deconstruction. n.d. In: Wikipedia. http://en.wikipedia.org/wiki/Deconstruction (Accessed 26 August 2006).

De Figueiredo JP, Elkins Z. 2003. Are patriots bigots? An inquiry into the vices of in-group pride. American Journal of Political Science 47(1): 171-191. http://dx.doi.org/10.1111/1540-5907.00012.

De Keere K, Elchardus M. 2011. Narrating linguistic conflict: A storytelling analysis of the language conflict in Belgium. Journal of Multilingual and Multicultural Development (32)3: 221-234. http:// dx.doi.org/10.1080/01434632.2011.563857. 
Deumert A. 2010. Tracking the demographics of (urban) language shift - an analysis of South African census data. Journal of Multilingual and Multicultural Development (1): 13-35.

Delrue K. 2003. Zure druiven, zoete krenten? Een schooletnografish onderzoek in het secundair onderwys. Gent: Steunpunt Intercultureel Onderwijs.

Delrue K, Loobuyck P, Pelleriaux K, Sierens S, Van Houtte M. 2006. Nieuwe denksporen voor een gelijkekansenbeleid in het onderwijs. Samenleving en politiek, 13(3): 22-29.

Du Plessis T. 2014. The South African Language Rights Monitor and information on language policy and planning in South Africa. Language Matters 45(3): 378-400. https://doi.org/10.1080/1022819 5.2014 .981571

Du Plessis H, Du Plessis T (eds). 1987. Afrikaans en taalpolitiek, 15 opstelle. Pretoria: HAUM.

El Sgiar H. 2015. Personal conversation on 28 January.

Engelbrecht A. 2008. The impact of role reversal in representational practices in history textbooks after apartheid. South African Journal of Education 28: 519-541.

Engelbrecht A. 2009. Kultuurstereotipering in Nederlandse, Vlaamse en Afrikaanse moedertaaltaalhandboeke. Unpublished PhD thesis. University of Pretoria.

Esterhuyse J. 1986. Taalapartheid en skoolafrikaans. Emmarentia: Taurus.

Frankenberg R. 1988. White Women, Race Matters: The Social Construction of Whiteness. Minneapolis: University of Minnesota Press.

Gramsci A. 1971. Selections from the Prison Notebooks of Antonio Gramsci. New York: International Publishers

Hager M. 2007. Taalprobleme van die immigrantekinders in die Nederlandse klaskamer. Werkswinkel te Artevelde Hogeschool, Gent, 18 April 2007.

Harvey E. 2000. Afrikaans: the product of a racist history. Mail \& Guardian, 23 June.

Henry F, Tator C. 2006. The colour of democracy: Racism in Canadian society. 3rd edn. Toronto: Nelson.

Homan HDI (ed.). 2003. DIMPLE. Dissemination and implementation of help desks for intercultural Learning Materials. Utrecht: PAREL.

hooks b. 1992. Black looks: race and representation. Boston: South End Press.

Huckin TN. 2004. Social approaches to critical discourse analysis. Available at: http://exchanges. state.gov/education/engteaching/pubs/BR/functionalsec3-6.htm (Accessed 4 September).

Kusendila B. 2003. Language education and national identity - a comparative study of Flemish and Afrikaans L1 instruction materials since 2000. Unpublished MEd dissertation. University of Cape Town.

Lauwers T. 2006. Vlaamse lesse vir Afrikaans. Available at: http://www.geocities.com/groep 63/ lauwers035.htm (Accessed 11 August).

Le Cordeur M, Hamman HJR, Esterhuizen BJ, Van Niekerk A. 1999. Afrikaans ons taal. 11/12 (1st edn). Cape Town: Maskew Miller Longman.

Le Cordeur M, Hamman HJR, Esterhuizen BJ, Van Niekerk A. 2007. Afrikaans ons taal. 11/12 (2nd edn). Cape Town: Maskew Miller Longman.

Lesaffer P. 2007. In Antwerpse scholen spreken twee op drie thuis andere taal. De Standaard, 13 February.

Lubbe J, Du Plessis T. 2013. South African Language rights monitor 2008. Stellenbosch: African Sun Media.

McCormick K. 2002. Language in Cape Town's District 6. Cape Town: Oxford University Press.

Montgomery K. 2005. Imagining the anti-racist state: Representations of racism in Canadian history textbooks. Discourse: Studies in the Cultural Politics of Education 26(4): 427-442. http://dx.doi. org/10.1080/01596300500319712.

Painter NI. 2015. What is Whiteness? The New York Times, 20 June.

Pattynama P, Verboom M. 2000. Werkboek: Kleur in het curriculum, interculturaliteit in het hoger onderwijs. Utrecht: Utrecht Universiteit.

Pieterse HJ. 1994. Taalpolitiek en 'Alternatiewe Afrikaans'. Unpublished PhD thesis. UNISA.

Prosser J. 2001. Image-based research. Philadelphia: Routledge Falmer. 
Roose I, Pulinx R. 2014. Kleine kinderen grote kansen. Hoe kleuterleraars leren omgaan met armoede en ongelijkheid. Kortrijk: Jo Vandenbulcke BVBA.

Rose G. 2001. Visual methodologies. London: Sage.

Seale C, Gobo G, Gubrium JF, Silverman D. 2004. Qualitative research practice. London: Sage. http://dx.doi.org/10.4135/9781848608191.

Sierens S. 2007. Diversiteit in leren, leren in diversiteit: Burgerschapvorming en gelijke leerkansen in een pluforme samenleving. Gent: Steunpunt Diversiteit en Leren.

Sim S, Van Loon B. 2002. Introducing critical theory. New York: Totem.

Thompson A. 2001. Summary of Whiteness Theory. Available at: http://www.pauahtun.org/ Whiteness-Summary-1.html (Accessed 2 August).

Van der Elst J, Prinsloo D. 2011. Afrikaans + Onderwys = Uitnemendheid. Cape Town: Afrikaanse Taalraad.

Vandeyar 2014. Good practice in culture-rich classrooms. Research-informed perspectives. Cape Town: Oxford University Press.

Van Dijk TA. 1987. Schoolvoorbeelden van racisme. Amsterdam: SUA.

Van Dijk TA. 1993. Principles of critical discourse analysis. Discourse \& Society 4(2): 249-283. http:// dx.doi.org/10.1177/0957926593004002006.

Van Dijk T. 2008. Discourse and power. Palgrave: Macmillan. http://dx.doi. org/10.1007/978-1-137-07299-3.

Van Rensburg C (ed.). 1997. Afrikaans in Afrika. Pretoria: Van Schaik.

Wekker G. 2002. Nesten bouwen op een winderige plek: Denken over gender en etniciteit in Nederland. Faculteit der Letteren: Universiteit Utrecht.

Wodak, RE, Meyer, M. (eds). 2015. Methods of critical discourse studies. 3rd edn. London: Sage. 